\title{
An Efficient One-Pot Four-Component Synthesis of 9-Aryl-Hexahydroacridine-1,8-Dione Derivatives in the Presence of a Molecular Sieves Supported Iron Catalyst
}

\author{
Ágnes Magyar ${ }^{1} \cdot$ Zoltán Hell $^{1}$
}

Received: 12 March 2019 / Accepted: 26 May 2019 / Published online: 8 June 2019

(c) The Author(s) 2019

\begin{abstract}
A series of 9-aryl-hexahydroacridine-1,8-diones are synthetized with good to excellent yields (50-99\%) via a one-pot fourcomponent reaction of dimedone, aromatic aldehydes and ammonium acetate in the presence of $4 \AA$ molecular sieves modified with iron(III) as an efficient heterogeneous catalyst, in ethanol. The process offers the advantages of high yields, mild reaction conditions and easy work-up procedure. The catalyst can be reused without significant loss of activity.
\end{abstract}

\section{Graphic Abstract}

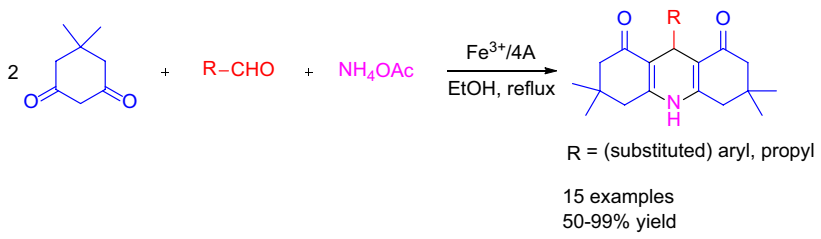

Keywords Heterogeneous catalysis · Multicomponent reactions · 9-Aryl-hexahydro-acridine-1,8-dione $\cdot$ Iron $\cdot 4 \AA$ Molecular sieves

\section{Introduction}

During the past years, multicomponent reactions (MCRs) have emerged as valuable and efficient tools in the hands of synthetic organic chemists, since they have several advantages over the classical synthetic strategies. MCRs provide complex organic compounds in a single step using simple and readily available substrates without the isolation of any intermediates under shorter reaction times, yielding less side products with lower energy consumption and waste production, thus leading to environmentally more friendly processes [1].

Zoltán Hell

zhell@mail.bme.hu

1 Department of Organic Chemistry and Technology, Budapest University of Technology and Economics, Múegyetem rkp.

3, 1111 Budapest, Hungary
Acridinediones are a highly important class of organic compounds, since they possess a wide range of pharmaceutical and biological activities such as a positive ionotropic effect promoting the entry of calcium to the intracellular space [2], anticancer activity [3], enzyme and tumour cell inhibition [4], antimicrobial activity and cytotoxicity [5]. They have structural similarity to 1,4-dihydropyridines (1,4DHPs), which are well known intermediates in the synthesis of several pharmaceuticals including those for the treatment of hypertension and cardiovascular diseases [6]. Acridine1,8-diones can also be used as laser dyes with very high lasing-efficiencies $[7,8]$.

Due to their importance, several strategies have been developed for the synthesis of 9-aryl-acridine-1,8-diones, including the thermal reaction of dimedone, different aromatic aldehydes and aqueous ammonia in ethanol [9], the microwave-irradiation-aided solvent-free reaction of dimedone and an aldehyde using alumina supported ammonium acetate and catalytic $N, N$-dimethylformamide [10], 
or ammonium bicarbonate [11], in water under microwave irradiation [12], and in pure water without any additives [13]. The use of ionic liquids alone $[14,15]$ and in the presence of $\mathrm{CeCl}_{3} \cdot 7 \mathrm{H}_{2} \mathrm{O}$ [16] was also reported for this conversion. Numerous protocols have been developed for the synthesis using different catalysts. As homogenous catalysts, $\mathrm{CuSO}_{4} \cdot 5 \mathrm{H}_{2} \mathrm{O}$ [17] and ceric ammonium nitrate and PEG [18] are described for the synthesis, and we can also find examples for heterogeneous catalysts such as HY-Zeolite [19], carbon-based solid acid (CBSA) [20], $\mathrm{Fe}_{3} \mathrm{O}_{4} @ \mathrm{SiO}_{2} @$ $\mathrm{Ni}-\mathrm{Zn}-\mathrm{Fe}$ LDH [21], mesoporous silica nanoparticles (MSNs) [22], and $\mathrm{Fe}_{3} \mathrm{O}_{4} @ \mathrm{SiO}_{2}$ nanoparticles [23].

Although the reported methods have their own advantages and limitations, a simple, easily accessible and reusable heterogeneous catalyst may have a synthetic importance.

The main research profile of our group is to elaborate new heterogeneous catalytic methods for the preparation of organic compounds in the presence of supported metal catalysts. Several metals have been used successfully in different organic syntheses, such as palladium [24-27], nickel [28], copper [29-32], titanium [33, 34], lanthanum [35, 36] and zinc [37] on different supports (Mg:La 3:1 mixed oxide, $4 \AA$ molecular sieves). In this paper we present a simple method for the one-pot four-component synthesis of 9-arylacridine-1,8-dione derivatives from dimedone, aldehydes and ammonium acetate in the presence of a slightly basic, 4 Å molecular sieves-supported iron catalyst $\left(\mathrm{Fe}^{3+} / 4 \mathrm{~A}\right)$.

\section{Experimental}

Morphology of the catalyst samples was investigated by a JEOL 6380LVa (JEOL, Tokyo, Japan) type scanning electron microscope and elemental mapping was also accomplished using the energy-dispersive X-ray detector of the equipment. Each specimen was fixed by conductive doublesided carbon adhesive tape and sputtered by gold (using a JEOL 1200 instrument). Applied accelerating voltage and working distance were between 15 and $30 \mathrm{kV}$ and 10 and $12 \mathrm{~mm}$, respectively. In the case of the comparison of the fresh and the used catalysts, the samples were examined without sputtering with gold and were not fixed on a carbon tape.

The nitrogen adsorption/desorption isotherms were measured at $-196{ }^{\circ} \mathrm{C}$ with a computer-controlled Nova 200e (Quantachrome) instrument. The apparent surface area $\left(\mathrm{S}_{\mathrm{BET}}\right)$ was calculated using the Brunauer-Emmett-Teller (BET) model. The total pore volume $\left(\mathrm{V}_{t}\right)$ was derived from the amount of vapour adsorbed at $\mathrm{p} / \mathrm{p}_{0} \rightarrow 1$, assuming that the pores were already filled with liquid adsorbate. The micropore volume $\left(\mathrm{W}_{0}\right)$ was derived from the Dubinin-Radushkevich (DR) plot. Prior to the adsorption measurement, the samples were evacuated at $110{ }^{\circ} \mathrm{C}$ for $24 \mathrm{~h}$.

${ }^{1} \mathrm{H}$ and ${ }^{13} \mathrm{C}$ NMR spectra were made on BRUKER Avance-500 instrument using TMS as an internal standard in $\mathrm{CDCl}_{3}$. All compounds and solvents were purchased from Merck Hungary Ltd.

\subsection{Preparation of the Catalyst}

Four Angstrom molecular sieves (4A) were impregnated with $\mathrm{FeCl}_{3} \times 6 \mathrm{H}_{2} \mathrm{O}$ as follows: $1 \mathrm{mmol}$ of the metal salt was dissolved in $100 \mathrm{ml}$ of deionised water and stirred with $1 \mathrm{~g}$ $4 \mathrm{~A}$ at room temperature for $24 \mathrm{~h}$. The solid was filtered, washed with deionised water and with acetone, then dried in an oven at $150{ }^{\circ} \mathrm{C}$ for $1 \mathrm{~h}$. Samples were heated at $120^{\circ} \mathrm{C}$ for $1 \mathrm{~h}$ before the reaction.

\subsection{Determination of the $\mathrm{pH}$ of the Catalyst}

The catalyst ( $1 \mathrm{~g}$ ) was stirred in $30 \mathrm{~mL}$ deionised water under continuous measuring of the $\mathrm{pH}$. The values were accepted after reaching a constant value at least during $10 \mathrm{~min}$.

\subsection{Typical Reaction Conditions}

\subsubsection{General Procedure for the One-Pot Synthesis of Acridinedione Derivatives}

A typical reaction was carried out in a $10 \mathrm{~mL}$ flask. Dimedone $(2 \mathrm{mmol})$, aldehyde $(1 \mathrm{mmol})$, ammonium acetate $(3 \mathrm{mmol}), \mathrm{Fe}^{3+} / 4 \mathrm{~A}(0.1 \mathrm{~g})$ and ethanol $(3 \mathrm{~mL})$ were stirred at reflux temperature for $14 \mathrm{~h}$. The progression of the reaction was monitored by TLC. After completion, the solid was filtered, and washed with ethanol, then the filtrate was evaporated. The residue was extracted with dichloromethane and $0.25 \mathrm{M} \mathrm{NaOH}$ solution. The organic phase was dried over anhydrous sodium sulphate, filtered and the solvent was evaporated. The product was subjected to ${ }^{1} \mathrm{H}$ and ${ }^{13} \mathrm{C}$ NMR spectroscopy.

All products have satisfactory spectral data $\left({ }^{1} \mathrm{H}\right.$ and ${ }^{13} \mathrm{C}$ NMR). The spectral data of the known compounds were identical with those reported in the literature.

\subsubsection{Characterisation of the Products}

9-Phenyl-3,3,6,6-tetramethyl-3,4,6,7,9,10-hexahydroacridine-1,8-dione, $4 \boldsymbol{a}$ yellow solid. ${ }^{1} \mathrm{H} \mathrm{NMR}\left(500 \mathrm{MHz}, \mathrm{CDCl}_{3}\right)$ $\delta(\mathrm{ppm}): 0.95$ (s, 6H); $1.06(\mathrm{~s}, 6 \mathrm{H}) ; 2.13-2.30(\mathrm{~m}, 8 \mathrm{H}) ; 5.09$ (s, 1H); $7.06(\mathrm{t}, J=7.5 \mathrm{~Hz}, 1 \mathrm{H}) ; 7.19(\mathrm{t}, J=7.5 \mathrm{~Hz}, 2 \mathrm{H})$; $7.34(\mathrm{~d}, J=7.0 \mathrm{~Hz}, 2 \mathrm{H}) ; 7.96(\mathrm{~s}, 1 \mathrm{H}) .{ }^{13} \mathrm{C}$ NMR $(125 \mathrm{MHz}$, $\mathrm{CDCl}_{3}$ ) $\delta$ (ppm): 27.17, 29.63, 32.67, 33.71, 40.77, 50.97, $113.31,126.04,128.01,146.70,149.22$, 195.94. Anal. 
Calcd. for $\mathrm{C}_{23} \mathrm{H}_{27} \mathrm{NO}_{2}: \mathrm{C} 79.08, \mathrm{H} 7.74, \mathrm{~N} 4.01 \%$, found: $\mathrm{C}$ 79.12, H 7.79, N 3.98\%.

9-(3-Bromophenyl)-3,3,6,6-tetramethyl-3,4,6,7,9,10hexahydroacridine-1,8-dione, $4 \boldsymbol{b}$ yellow solid. ${ }^{1} \mathrm{H}$ NMR $\left(500 \mathrm{MHz}, \mathrm{CDCl}_{3}\right) \delta$ (ppm): 0.97 (s, 6H); 1.08 (s, 6H); 2.13$2.38(\mathrm{~m}, 8 \mathrm{H}) ; 5.02(\mathrm{~s}, 1 \mathrm{H}) ; 7.05(\mathrm{t}, J=8.0 \mathrm{~Hz}, 1 \mathrm{H}) ; 7.17$ $(\mathrm{d}, J=8.0 \mathrm{~Hz}, 1 \mathrm{H}) ; 7.32(\mathrm{~d}, J=6.0 \mathrm{~Hz}, 1 \mathrm{H}) ; 7.40(\mathrm{~s}, 1 \mathrm{H})$; $8.16(\mathrm{~s}, 1 \mathrm{H}) .{ }^{13} \mathrm{C}$ NMR $\left(125 \mathrm{MHz}, \mathrm{CDCl}_{3}\right) \delta(\mathrm{ppm}): 26.96$, 29.29, 32.35, 39.91, 40.55, 50.54, 112.37, 121.74, 126.95, 128.59, 129.16, 130.66, 148.59, 195.00. Anal. Calcd. for $\mathrm{C}_{23} \mathrm{H}_{26} \mathrm{BrNO}_{2}$ : C 64.49, H 6.07, N 3.27\%, found: C 64.52, H 6.12, N 3.25\%.

9-(4-Bromophenyl)-3,3,6,6-tetramethyl-3,4,6,7,9,10hexahydroacridine-1,8-dione, $4 c$ yellow solid. ${ }^{1} \mathrm{H}$ NMR $\left(500 \mathrm{MHz}, \mathrm{CDCl}_{3}\right) \delta$ (ppm): 0.95 (s, 6H); 1.07 (s, 6H); 2.12$2.32(\mathrm{~m}, 8 \mathrm{H}) ; 5.03(\mathrm{~s}, 1 \mathrm{H}) ; 7.22(\mathrm{~d}, J=8.5 \mathrm{~Hz}, 2 \mathrm{H}) ; 7.29(\mathrm{~d}$, $J=8.5 \mathrm{~Hz}, 2 \mathrm{H}) ; 8.45(\mathrm{~s}, 1 \mathrm{H}) .{ }^{13} \mathrm{C} \mathrm{NMR}\left(125 \mathrm{MHz}, \mathrm{CDCl}_{3}\right)$ $\delta$ (ppm): 27.17, 29.65, 32.63, 40.67, 50.90, 112.70, 119.65, 129.99, 130.97, 145.99, 149.44, 195.79. Anal. Calcd. for $\mathrm{C}_{23} \mathrm{H}_{26} \mathrm{BrNO}_{2}$ : C 64.49, H 6.07, N 3.27\%, found: C 64.54, H 6.09, N 3.29\%.

9-(2-Chlorophenyl)-3,3,6,6-tetramethyl-3,4,6, 7,9,10hexahydroacridine-1,8-dione, $4 d$ yellow solid. ${ }^{1} \mathrm{H}$ NMR $\left(500 \mathrm{MHz}, \mathrm{CDCl}_{3}\right) \delta$ (ppm): 0.95 (s, 6H); 1.07 (s, 6H); 2.02$2.39(\mathrm{~m}, 8 \mathrm{H}) ; 5.25(\mathrm{~s}, 1 \mathrm{H}) ; 6.98(\mathrm{t}, J=8.0 \mathrm{~Hz}, 1 \mathrm{H}) ; 7.09$ (t, $J=7.5 \mathrm{~Hz}, 1 \mathrm{H}) ; 7.18(\mathrm{~d}, J=7.5 \mathrm{~Hz}, 1 \mathrm{H}) ; 7.39(\mathrm{~d}, J=8.0 \mathrm{~Hz}$, $1 \mathrm{H}) ; 8.84$ (s, 1H). ${ }^{13} \mathrm{C} \mathrm{NMR}\left(125 \mathrm{MHz}, \mathrm{CDCl}_{3}\right) \delta(\mathrm{ppm})$ : 26.86, 29.34, 32.08, 39.91, 40.31, 50.60, 111.60, 125.89, 126.64, 129.19, 131.91, 132.86, 143.82, 149.38, 194.87. Anal. Calcd. for $\mathrm{C}_{23} \mathrm{H}_{26} \mathrm{ClNO}_{2}$ : C 72.06, H 6.79, N 3.66\%, found: C 72.11, H 6.82, N 3.61\%.

9-(4-Chlorophenyl)-3,3,6,6-tetramethyl-3,4,6,7,9,10hexahydroacridine-1,8-dione, $4 \boldsymbol{e}$ yellow solid. ${ }^{1} \mathrm{H}$ NMR $\left(500 \mathrm{MHz}, \mathrm{CDCl}_{3}\right) \delta(\mathrm{ppm}): 0.95$ (s, 6H); 1.07 (s, 6H); 2.17$2.29(\mathrm{~m}, 8 \mathrm{H}) ; 5.07(\mathrm{~s}, 1 \mathrm{H}) ; 7.16(\mathrm{~d}, J=8.5 \mathrm{~Hz}, 2 \mathrm{H}) ; 7.29$ (d, $J=8.5 \mathrm{~Hz}, 2 \mathrm{H}) ; 8.49$ (s, 1H). ${ }^{13} \mathrm{C}$ NMR $\left(125 \mathrm{MHz}, \mathrm{CDCl}_{3}\right)$ $\delta$ (ppm): 27.17, 29.69, 32.72, 40.70, 50.98, 112.85, 128.19, 129.57, 131.65, 145.39, 149.79, 196.16. Anal. Calcd. for $\mathrm{C}_{23} \mathrm{H}_{26} \mathrm{ClNO}_{2}$ : C 72.06, H 6.79, N 3.66\%, found: C 72.09, $\mathrm{H} 6.80, \mathrm{~N} 3.63 \%$.

9-(2-Fluorophenyl)-3,3,6,6-tetramethyl-3,4,6,7,9,10hexahydroacridine-1,8-dione, $4 f$ yellow solid. ${ }^{1} \mathrm{H}$ NMR $\left(500 \mathrm{MHz}, \mathrm{CDCl}_{3}\right) \delta(\mathrm{ppm}): 0.94(\mathrm{~s}, 6 \mathrm{H}) ; 1.05(\mathrm{~s}, 6 \mathrm{H})$; 2.10-2.30 (m, 8H); $5.24(\mathrm{~s}, 1 \mathrm{H}) ; 6.89(\mathrm{t}, J=9.5 \mathrm{~Hz}, 1 \mathrm{H})$; 6.99-7.08 (m, 2H); $7.45(\mathrm{t}, J=7.5 \mathrm{~Hz}, 1 \mathrm{H}) ; 8.01(\mathrm{~s}, 1 \mathrm{H})$. ${ }^{13} \mathrm{C}$ NMR (125 MHz, $\mathrm{CDCl}_{3}$ ) $\delta$ (ppm): 26.91, 29.64, 32.59, 40.69, 50.92, 111.77, 115.20, 123.56, 127.64, 131.69, 133.04, 149.71, 195.81. Anal. Calcd. for $\mathrm{C}_{23} \mathrm{H}_{26} \mathrm{FNO}_{2}: \mathrm{C}$ 75.20, H 7.08, N 3.81\%, found: C 75.25, H 7.11, N 3.75\%.

9-(2-Methylphenyl)-3,3,6,6-tetramethyl-3,4,6,7,9,10hexahydroacridine-1,8-dione, $\mathbf{4 g}$ yellow solid. ${ }^{1} \mathrm{H}$ NMR $\left(500 \mathrm{MHz}, \mathrm{CDCl}_{3}\right) \delta(\mathrm{ppm}): 0.92(\mathrm{~s}, 6 \mathrm{H}) ; 1.06$ $(\mathrm{s}, 6 \mathrm{H}) ; 2.05-2.37(\mathrm{~m}, 8 \mathrm{H}) ; 2.84(\mathrm{~s}, 3 \mathrm{H}) ; 5.06(\mathrm{~s}, 1 \mathrm{H})$; $6.91(\mathrm{t}, J=8.0 \mathrm{~Hz}, 1 \mathrm{H}) ; 6.97(\mathrm{t}, J=7.5 \mathrm{~Hz}, 2 \mathrm{H}) ; 7.08$ (d, $J=7.5 \mathrm{~Hz}, 1 \mathrm{H}) ; 8.39(\mathrm{~s}, 1 \mathrm{H}) .{ }^{13} \mathrm{C} \mathrm{NMR}\left(125 \mathrm{MHz}, \mathrm{CDCl}_{3}\right)$ $\delta$ (ppm): 19.34, 26.39, 28.92, 31.89, 40.05, 50.30, 113.92, 125.01, 127.58, 128.96, 129.02, 129.06, 135.56, 146.09, 148.14, 195.07. Anal. Calcd. for $\mathrm{C}_{24} \mathrm{H}_{29} \mathrm{NO}_{2}: \mathrm{C} 79.34, \mathrm{H}$ 7.99, N 3.86\%, found: C 79.37, H 8.04, N 3.81\%.

9-(3-Methylphenyl)-3,3,6,6-tetramethyl-3,4,6,7,9,10hexahydroacridine-1,8-dione, $4 \boldsymbol{h}$ yellow solid. ${ }^{1} \mathrm{H}$ NMR $\left(500 \mathrm{MHz}, \mathrm{CDCl}_{3}\right) \delta(\mathrm{ppm}): 0.95(\mathrm{~s}, 6 \mathrm{H}) ; 1.06(\mathrm{~s}, 6 \mathrm{H})$; $2.10-2.32(\mathrm{~m}, 11 \mathrm{H}) ; 5.01(\mathrm{~s}, 1 \mathrm{H}) ; 6.85(\mathrm{~d}, J=7.0 \mathrm{~Hz}, 1 \mathrm{H})$; 7.03-7.09 (m, 2H); $7.14(\mathrm{~s}, 1 \mathrm{H}) ; 8.40(\mathrm{~s}, 1 \mathrm{H}) .{ }^{13} \mathrm{C} \mathrm{NMR}$ $\left(125 \mathrm{MHz}, \mathrm{CDCl}_{3}\right) \delta$ (ppm): 21.56, 27.05, 29.57, 32.50, $40.57,50.88,112.98,125.01,126.55,127.68,128.92$, 136.94, 146.78, 149.11, 149.17, 195.56. Anal. Calcd. for $\mathrm{C}_{24} \mathrm{H}_{29} \mathrm{NO}_{2}$ : C 79.34, $\mathrm{H} 7.99, \mathrm{~N} 3.86 \%$, found: C 79.35, H $8.02, \mathrm{~N} 3.83 \%$.

9-(4-Methylphenyl)-3,3,6,6-tetramethyl-3,4,6,7,9,10hexahydroacridine-1,8-dione, $4 i$ yellow solid. ${ }^{1} \mathrm{H}$ NMR $\left(500 \mathrm{MHz}, \mathrm{CDCl}_{3}\right) \delta(\mathrm{ppm}): 0.95(\mathrm{~s}, 6 \mathrm{H}) ; 1.05(\mathrm{~s}, 6 \mathrm{H})$; $2.12-2.28(\mathrm{~m}, 11 \mathrm{H}) ; 5.06(\mathrm{~s}, 1 \mathrm{H}) ; 6.99(\mathrm{~d}, J=8.0 \mathrm{~Hz}, 2 \mathrm{H})$; $7.22(\mathrm{~d}, J=8.0 \mathrm{~Hz}, 2 \mathrm{H}) ; 8.50(\mathrm{~s}, 1 \mathrm{H}) .{ }^{13} \mathrm{C} \mathrm{NMR}(125 \mathrm{MHz}$, $\left.\mathrm{CDCl}_{3}\right) \delta(\mathrm{ppm}): 21.09,27.08,29.55,32.55,40.51,50.99$, 113.09, 127.88, 128.67, 135.14, 143.86, 149.79, 196.13 . Anal. Calcd. for $\mathrm{C}_{24} \mathrm{H}_{29} \mathrm{NO}_{2}$ : C 79.34, H 7.99, N 3.86\%, found: $\mathrm{C} 79.38, \mathrm{H} 8.05, \mathrm{~N} 3.86 \%$.

9-(2-Methoxyphenyl)-3,3,6,6-tetramethyl-3,4,6,7,9,10hexahydroacridine-1,8-dione, $4 \boldsymbol{k}$ yellow solid. ${ }^{1} \mathrm{H}$ NMR $\left(500 \mathrm{MHz}, \mathrm{CDCl}_{3}\right) \delta(\mathrm{ppm}): 0.90(\mathrm{~s}, 6 \mathrm{H}) ; 1.04(\mathrm{~s}, 6 \mathrm{H})$; 2.02-2.33 (m, 8H); $3.78(\mathrm{~s}, 3 \mathrm{H}) ; 5.16(\mathrm{~s}, 1 \mathrm{H}) ; 6.75-6.80$ $(\mathrm{m}, 2 \mathrm{H}) ; 7.03(\mathrm{t}, J=7.5 \mathrm{~Hz}, 1 \mathrm{H}) ; 7.37(\mathrm{~d}, J=7.0 \mathrm{~Hz}$, $1 \mathrm{H}) ; 8.62(\mathrm{~s}, 1 \mathrm{H}) .{ }^{13} \mathrm{C}$ NMR $\left(125 \mathrm{MHz}, \mathrm{CDCl}_{3}\right) \delta(\mathrm{ppm})$ : 26.44, 29.67, 32.28, 50.89, 55.19, 110.66, 111.37, 119.76, 126.86, 131.57, 133.94, 149.62, 157.63, 195.21. Anal. Calcd. for $\mathrm{C}_{24} \mathrm{H}_{29} \mathrm{NO}_{3}$ : C 75.99, H 7.65, N 3.69\%, found: C 76.03, H 7.68, N 3.64\%.

9-(4-Methoxyphenyl)-3,3,6,6-tetramethyl-3,4,6,7,9,10hexahydroacridine-1,8-dione, $4 \mathrm{l}$ yellow solid. ${ }^{1} \mathrm{H} \mathrm{NMR}$ $\left(500 \mathrm{MHz}, \mathrm{CDCl}_{3}\right) \delta(\mathrm{ppm}): 0.95(\mathrm{~s}, 6 \mathrm{H}) ; 1.06(\mathrm{~s}, 6 \mathrm{H})$; 2.12-2.28 (m, 8H); $3.67(\mathrm{~s}, 3 \mathrm{H}) ; 5.04(\mathrm{~s}, 1 \mathrm{H}) ; 6.71(\mathrm{~d}$, $J=8.5 \mathrm{~Hz}, 2 \mathrm{H}) ; 7.24(\mathrm{~d}, J=8.5 \mathrm{~Hz}, 2 \mathrm{H}) ; 7.92(\mathrm{~s}, 1 \mathrm{H}) .{ }^{13} \mathrm{C}$ NMR (125 MHz, $\left.\mathrm{CDCl}_{3}\right) \delta(\mathrm{ppm}): 27.11,29.57,32.59$, 40.66, 50.89, 55.01, 113.29, 113.39, 128.93, 139.18, 148.96, 157.64, 195.99. Anal. Calcd. for $\mathrm{C}_{24} \mathrm{H}_{29} \mathrm{NO}_{3}: \mathrm{C}$ 75.99, H 7.65, N 3.69\%, found: C 76.05, H 7.71, N 3.65\%.

9-(2-Nitrophenyl)-3,3,6,6-tetramethyl-3,4,6,7,9,10hexahydroacridine-1,8-dione, $4 m$ yellow solid. ${ }^{1} \mathrm{H}$ NMR $\left(500 \mathrm{MHz}, \mathrm{CDCl}_{3}\right) \delta(\mathrm{ppm}): 0.92(\mathrm{~s}, 6 \mathrm{H}) ; 1.03(\mathrm{~s}, 6 \mathrm{H})$; $2.07-2.32(\mathrm{~m}, 8 \mathrm{H}) ; 5.30(\mathrm{~s}, 1 \mathrm{H}) ; 7.19(\mathrm{t}, J=8.5 \mathrm{~Hz}, 1 \mathrm{H})$; $7.45-7.50(\mathrm{~m}, 2 \mathrm{H}) ; 7.71(\mathrm{~d}, J=8.0 \mathrm{~Hz}, 1 \mathrm{H}) ; 8.20(\mathrm{~s}, 1 \mathrm{H})$. ${ }^{13} \mathrm{C}$ NMR $\left(125 \mathrm{MHz}, \mathrm{CDCl}_{3}\right) \delta$ (ppm): 27.27, 29.17, $32.35,40.55,50.66,112.15,123.89,126.31,130.82$, 130.84, 131.98, 141.27, 149.71, 195.17. Anal. Calcd. for 
$\mathrm{C}_{23} \mathrm{H}_{26} \mathrm{~N}_{2} \mathrm{O}_{4}$ : C 70.05, H 6.60, N 7.11\%, found: C 70.11, $\mathrm{H} 6.65, \mathrm{~N} 7.05 \%$.

9-(3-Nitrophenyl)-3,3,6,6-tetramethyl-3,4,6,7,9,10hexahydroacridine-1,8-dione, $4 m$ yellow solid. ${ }^{1} \mathrm{H}$ NMR $\left(500 \mathrm{MHz}, \mathrm{CDCl}_{3}\right) \delta$ (ppm): 0.95 (s, 6H); 1.09 (s, 6H); 2.11$2.43(\mathrm{~m}, 8 \mathrm{H}) ; 5.15(\mathrm{~s}, 1 \mathrm{H}) ; 7.37(\mathrm{t}, J=7.5 \mathrm{~Hz}, 1 \mathrm{H}) ; 7.80(\mathrm{~d}$, $J=7.5 \mathrm{~Hz}, 1 \mathrm{H}) ; 7.92(\mathrm{~d}, J=7.5 \mathrm{~Hz}, 1 \mathrm{H}) ; 8.11(\mathrm{~s}, 1 \mathrm{H}) ; 8.66$ (s, $1 \mathrm{H}) .{ }^{13} \mathrm{C}$ NMR $\left(125 \mathrm{MHz}, \mathrm{CDCl}_{3}\right) \delta$ (ppm): 27.03, 29.47, $32.50,40.54,50.65,111.95,120.82,122.57,128.50,134.96$, 149.65, 195.31. Anal. Calcd. for $\mathrm{C}_{23} \mathrm{H}_{26} \mathrm{~N}_{2} \mathrm{O}_{4}$ : C 70.05, H 6.60, N 7.11\%, found: C 70.09, H 6.67, N 7.06\%.

9-(4-Nitrophenyl)-3,3,6,6-tetramethyl-3,4,6,7,9,10hexahydroacridine-1,8-dione, $4 \boldsymbol{n}$ yellow solid. ${ }^{1} \mathrm{H}$ NMR $\left(500 \mathrm{MHz}, \mathrm{CDCl}_{3}\right) \delta$ (ppm): $0.94(\mathrm{~s}, 6 \mathrm{H}) ; 1.08(\mathrm{~s}, 6 \mathrm{H})$; $2.11-2.42(\mathrm{~m}, 8 \mathrm{H}) ; 5.14(\mathrm{~s}, 1 \mathrm{H}) ; 7.51(\mathrm{~d}, J=8.0 \mathrm{~Hz}, 2 \mathrm{H})$; $8.06(\mathrm{~d}, J=8.0 \mathrm{~Hz}, 2 \mathrm{H}) ; 11.91(\mathrm{~s}, 1 \mathrm{H}) .{ }^{13} \mathrm{C}$ NMR $(125 \mathrm{MHz}$, $\mathrm{CDCl}_{3}$ ) $\delta$ (ppm): 27.08, 29.51, 32.47, 34.49, 50.68, 111.57, 123.02, 129.04,145.82, 149.82, 154.66, 195.09. Anal. Calcd. for $\mathrm{C}_{23} \mathrm{H}_{26} \mathrm{~N}_{2} \mathrm{O}_{4}$ : C 70.05, H 6.60, N 7.11\%, found: C 70.12, H 6.65, N 7.04\%.

9-Propyl-3,3,6,6-tetramethyl-3,4,6,7,9,10-hexahydroacridine-1,8-dione, 4 o yellow solid. ${ }^{1} \mathrm{H}$ NMR $\left(500 \mathrm{MHz}, \mathrm{CDCl}_{3}\right)$ $\delta$ (ppm): 0.79 (s, 3H); 1.08 (s, 12H); 1.21-1.29 (m, 2H); 2.18 (s, 4H); 2.31 (s, 4H); 3.27 (s, 2H); $3.93(\mathrm{~s}, 1 \mathrm{H}) ; 8.72$ (s, 1H). ${ }^{13} \mathrm{C} \mathrm{NMR}\left(125 \mathrm{MHz}, \mathrm{CDCl}_{3}\right) \delta(\mathrm{ppm}): 14.75,18.92,27.31$, 30.03, 32.56, 37.97, 40.87, 51.32, 66.10, 112.29, 150.59, 196.06. Anal. Calcd. for $\mathrm{C}_{20} \mathrm{H}_{29} \mathrm{NO}_{2}$ : C 76.19, H 9.21, N 4.44\%, found: C 76.25, H 9.27, N 4.43\%.

\section{Results and Discussion}

We investigated the structure of the $\mathrm{Fe}^{3+} / 4 \mathrm{~A}$ catalyst by scanning electron microscopy (SEM). During the impregnation procedure the molecular sieves support preserved its characteristic cuboctahedron shape as can be seen on Fig. 1. The average particle size ranged from 6 to $8 \mu \mathrm{m}$, and the particles are well defined both in shape and size. The iron is evenly distributed on the surface of the support, EDS measurement showed $5.14 \mathrm{w} / \mathrm{w} \%$ iron on the surface. The iron content of the catalyst determined by ICP-OES is concordant with the theoretical value $(5.3 \mathrm{w} / \mathrm{w} \%)$, thus it can be concluded that the metal is mainly situated on the surface of the support. The nitrogen adsorption/desorption measurements showed a considerable decrease in the surface of the support as well, the specific surface of $4 \mathrm{~A}$ dropped from 800 to $106.065 \mathrm{~m}^{2} / \mathrm{g}$. The total pore volume of the molecular sieves altered from 0.3 to $0.11 \mathrm{~cm}^{3} / \mathrm{g}$, the micropore volume was $0.022 \mathrm{~cm}^{3} / \mathrm{g}$. The catalysts $\mathrm{pH}$ value is 8.42 , so it is in the slightly basic region.

Recently, we reported the efficient synthesis of polyhydroquinolines via Hantzsch reaction in the presence of a molecular sieves supported lanthanum catalyst [36]. As

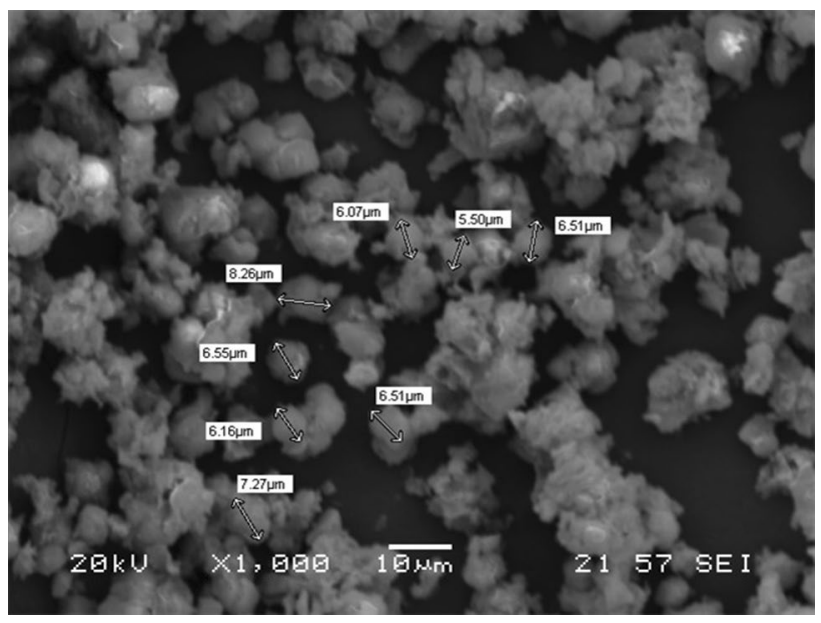

Fig. 1 SEM image of the catalyst

Table 1 The reaction of dimedone, 4-chlorobenzaldehyde and ammonium acetate in the presence of $\mathrm{La}^{3+} / 4 \mathrm{~A}$

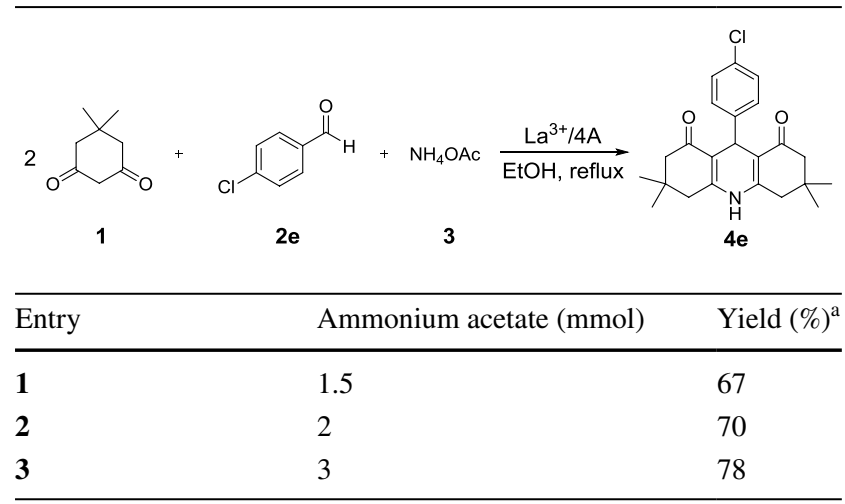

Reaction conditions: $2 \mathrm{mmol}$ dimedone, $1 \mathrm{mmol}$ 4-chlorobenzaldehyde, $1.5-3 \mathrm{mmol}$ ammonium acetate, $0.1 \mathrm{~g}$ catalyst, $3 \mathrm{~mL} \mathrm{EtOH}$, reflux, $14 \mathrm{~h}$

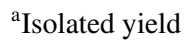

acridinediones are structurally similar to 1,4-DHPs, first we tested our $\mathrm{La}^{3+} / 4 \mathrm{~A}$ catalyst in the synthesis of 9-aryl-acridine-1,8-dione derivatives. As a model reaction, we investigated the reaction of dimedone, 4-chlorobenzaldehyde and ammonium acetate applying the previously elaborated reaction conditions. With the use of $1.5 \mathrm{mmol}$ ammonium acetate, the yield of the desired product was only $67 \%$, hence we attempted to increase the yield of the product applying excess of ammonium acetate. The results are summarised in Table 1 .

Since the yields were not satisfactory, we investigated the model reaction applying other molecular sieves supported metal catalysts. The results are shown in Table 2 .

The best result was obtained with $\mathrm{Fe}^{3+} / 4 \mathrm{~A}$, the desired product was formed with complete conversion (99\% isolated yield, Table 2, entry 7). In the case of the $\mathrm{Cu}^{2+} / 4 \mathrm{~A}$ catalyst, the metal dissolved into the reaction mixture from 
Table 2 The reaction of dimedone, 4-chlorobenzaldehyde and ammonium acetate in the presence of different molecular sieves supported metal catalysts

\begin{tabular}{lll}
\hline $\mathbf{2}$ & & \\
\hline $\mathbf{2}$ & $\mathrm{Catalyst}$ & $\mathrm{Yield}(\%)^{\mathrm{a}}$ \\
$\mathbf{3}$ & $4 \mathrm{~A}$ & $-{ }^{\mathrm{b}}$ \\
$\mathbf{4}$ & $\mathrm{La}^{3+} / 4 \mathrm{~A}$ & 96 \\
$\mathbf{5}$ & $\mathrm{Cu}^{2+} / 4 \mathrm{~A}$ & 93 \\
$\mathbf{6}$ & $\mathrm{Ti}^{4+} / 4 \mathrm{~A}$ & 92 \\
$\mathbf{7}$ & $\mathrm{Zn}^{2+} / 4 \mathrm{~A}$ & 99 \\
\hline $\mathrm{Zr}^{4+} / 4 \mathrm{~A}$ & $\mathrm{Fe}^{3+} / 4 \mathrm{~A}$ & $\mathbf{3}$ \\
\hline
\end{tabular}

Reaction conditions: $2 \mathrm{mmol}$ dimedone, $1 \mathrm{mmol}$ 4-chlorobenzaldehyde, $3 \mathrm{mmol}$ ammonium acetate, $0.1 \mathrm{~g}$ catalyst, $3 \mathrm{~mL} \mathrm{EtOH}$, reflux, $14 \mathrm{~h}$

${ }^{\mathrm{a}}$ Isolated yield

${ }^{\mathrm{b}}$ Unidentifiable and inseparable side products were also obtained

${ }^{\mathrm{c}}$ The product was contaminated by copper

the surface of the support probably because of a complex formation between copper and ammonium acetate, thus contaminated the product. Titanium, zinc and zirconium were less active; while in their ${ }^{1} \mathrm{H}$ NMR spectra small impurities could be detected.

Based on the reaction conditions elaborated, a wide range of aromatic aldehydes were reacted with dimedone and ammonium acetate in the $\mathrm{Fe}^{3+} / 4 \mathrm{~A}$ catalysed one-pot synthesis of 9-aryl-acridine-1,8-diones. The results are summarized in Table 3.

Benzaldehyde and other substituted aromatic aldehydes containing electron-withdrawing or electron-donating groups were tested in the reaction and gave the desired product in good to excellent yields. There was no significant substituent effect observed; only the nitro-derivatives (Table 3, entries 12-14) showed slightly weaker reactivity. In the case of the 2-nitro-derivate, another product could be isolated from the reaction mixture, which, based on the NMR spectra, proved to be the enol form of the desired product. The structure of this enol form can be seen on Fig. 2. This form might be stabilized by the H-bond formation between the hydroxyl and the nitro groups.

As an example for aliphatic aldehydes, we examined the reaction of butyraldehyde (Table 3, entry 15), that gave the desired product with moderate yield, no secondary product was observed. We also investigated the applicability of heteroaryl aldehydes (furfural, thiophene-2-carbaldehyde) in
Table 3 The synthesis of acridinedione derivatives in the presence of $\mathrm{Fe}^{3+} / 4 \mathrm{~A}$

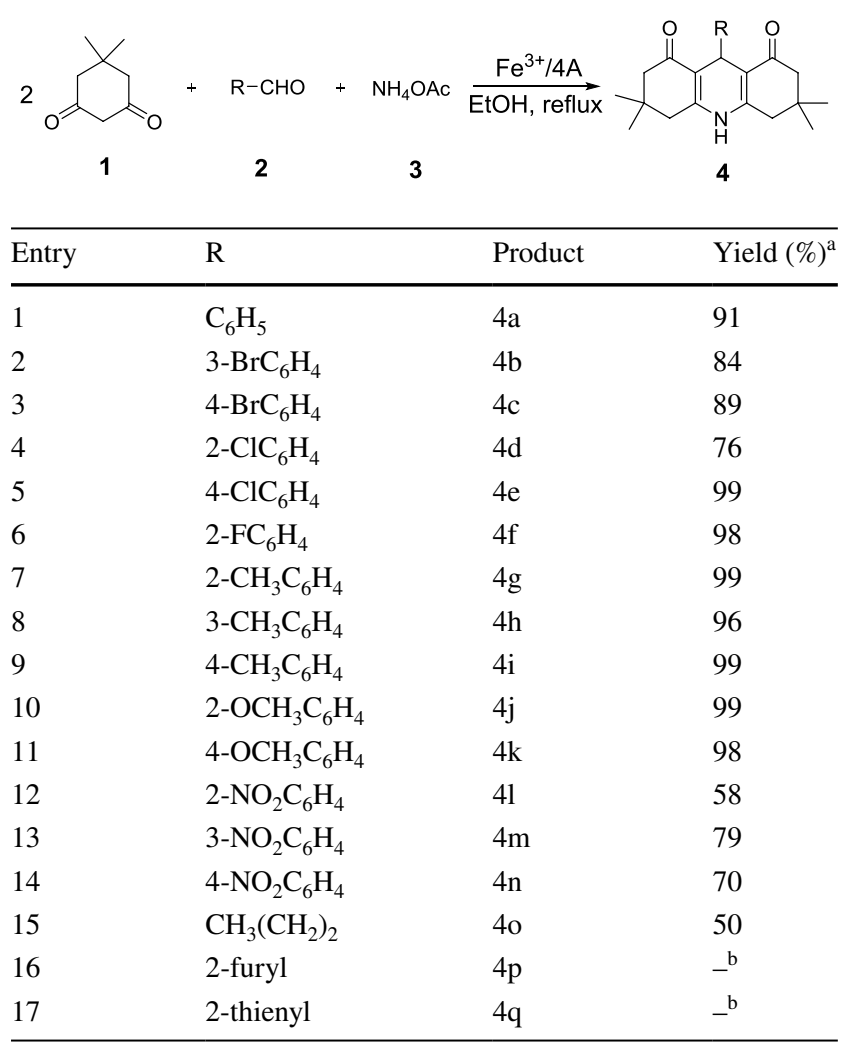

Reaction conditions: $2 \mathrm{mmol}$ dimedone, $1 \mathrm{mmol}$ aldehyde, $3 \mathrm{mmol}$ ammonium acetate, $0.1 \mathrm{~g}$ catalyst, $3 \mathrm{~mL}$ EtOH, reflux, $14 \mathrm{~h}$

${ }^{\mathrm{a}}$ Isolated yield

${ }^{\mathrm{b}}$ Complex reaction mixture was formed

Fig. 2 The structure of $\mathbf{4 l}^{\prime}$<smiles>CC1(C)CC2=NC3=C(C(=O)CC(C)(C)C3)C(c3ccccc3[N+](=O)[O-])C2=C(O)C1</smiles>

the condensation reaction, but in these cases complex reaction mixtures were formed.

We propose a plausible mechanism for the synthesis of 9-aryl-acridine-1,8-dione derivatives involving a Knoevenagel condensation, a Michael addition, and an intramolecular ring closure in the presence of a $4 \AA$ molecular sieves-supported iron catalyst (Scheme 1). The mechanism is similar to the one described by Dam et al. [23]. We have identified two intermediates, thus the Knoevenagel intermediate (D) could be detected in the GC-MS and NMR spectra when the reaction was interrupted before completion. When the reaction was carried out in the absence of ammonium 

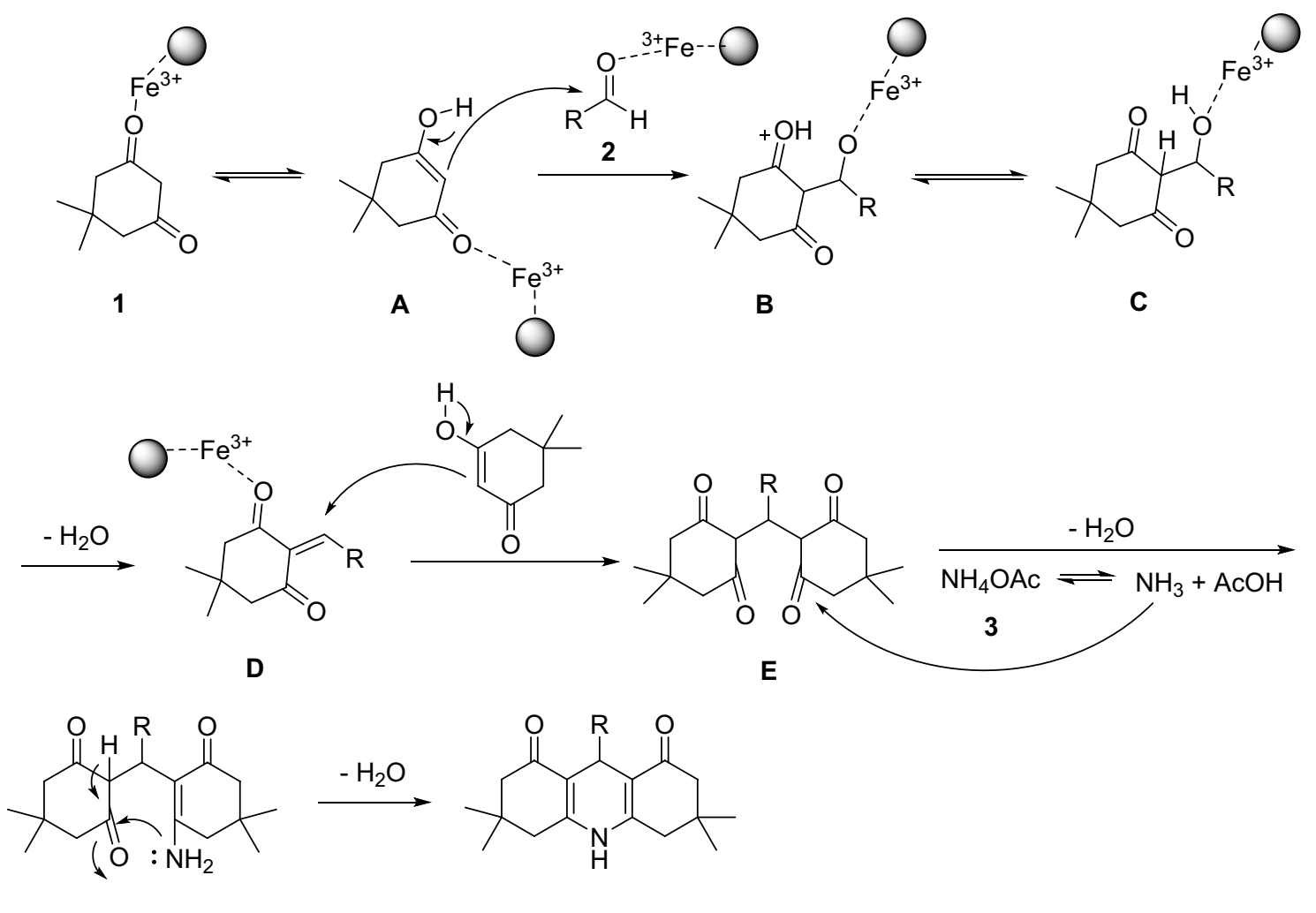

$\mathbf{F}$

Scheme 1 Proposed mechanism of the reaction

acetate, intermediate E could be isolated. The role of the iron might be to facilitate the reaction steps through the coordination of the heteroatoms in the transition states.

The workup of the reaction mixtures was rather simple; at the end of the reaction the catalyst was filtered out and washed with ethanol. The filtrate was evaporated, and the crude product obtained was extracted with DCM and $0.25 \mathrm{M}$ $\mathrm{NaOH}$ solution. The organic phase was dried over anhydrous sodium sulphate, filtered and the solvent was evaporated.

The reusability of the catalysts was examined in the reaction of dimedone, 4-chlorobenzaldehyde and ammonium acetate. After $14 \mathrm{~h}$ reflux, the reaction mixture was worked up as described above, then the catalyst was heated at ca. $150{ }^{\circ} \mathrm{C}$ for $1 \mathrm{~h}$. The catalyst was reused in two more runs without the significant loss of its activity. The yields in the 1st, 2nd and 3rd runs were 99, 98 and $98 \%$, respectively. These results clearly demonstrate the reusability of the $\mathrm{Fe}^{3+} / 4 \mathrm{~A}$ catalyst.

The use of a heterogeneous catalyst often induces a dispute over whether the reaction takes place on the solid surface of the catalyst or in the liquid phase through the leaching of the metal. To determine the heterogeneous or homogeneous nature of the reaction, we used the hot filtration test. The reaction is interrupted; the catalyst is filtered out, than the filtrate is reacted further. In case of the leaching of the metal, the conversion necessarily increases further, otherwise the reaction stops without the catalyst. We carried out the hot filtration test in the reaction of dimedone, 4-chlorobenzaldehyde and ammonium acetate. After $5 \mathrm{~h}$ the catalyst was filtered, the filtrate was divided into two fractions, one was worked up, and the other was reacted further for the rest of the reaction time. After $14 \mathrm{~h}$, the latter one was worked up as well. The two fractions were subjected to ${ }^{1} \mathrm{H}$ NMR spectroscopy. There was no difference between the two spectra, thus the leaching of the metal was not observable.

In order to evaluate the efficiency of our catalyst with respect to the previously reported catalysts for the preparation of acridinedione derivatives, we compared our results with the methods reported in the literature for this synthesis. The comparison is shown in Table 4. In contrast to the homogeneous catalysts, e.g. $\mathrm{CuSO}_{4} \cdot 5 \mathrm{H}_{2} \mathrm{O}$ and CAN, a heterogeneous catalyst has several advantages; it can be easily separated from the reaction mixture thus the product is not contaminated by the catalyst. Although solvent-free methods have been described, during the isolation and purification of the products, solvents had to be applied and the preparation of the catalysts have often been a complex procedure consisting of several steps (e.g. CBSA, $\mathrm{Fe}_{3} \mathrm{O}_{4} @ \mathrm{SiO}_{2} @$ $\mathrm{Ni}-\mathrm{Zn}-\mathrm{Fe} \mathrm{LDH}, \mathrm{MSNs}, \mathrm{Fe}_{3} \mathrm{O}_{4} @ \mathrm{SiO}_{2}$ nanoparticles). As it 
Table 4 Comparison of the efficiencies of different catalysts for the synthesis of acridinedione derivatives from dimedone (1), aromatic aldehydes (2a-n) and ammonium acetate (3)

\begin{tabular}{lllll}
\hline Catalyst & Solvent & Temperature $\left({ }^{\circ} \mathrm{C}\right)$ & Yield $(\%)$ & References \\
\hline $\mathrm{CuSO}_{4} \cdot 5 \mathrm{H}_{2} \mathrm{O}$ & $\mathrm{H}_{2} \mathrm{O}-\mathrm{EtOH}(1: 1)$ & 80 & $84-94$ & {$[17]$} \\
$\mathrm{CAN}$ & $\mathrm{PEG} 400$ & 25 & $91-98$ & {$[18]$} \\
$\mathrm{HY}-\mathrm{Zeolite}$ & $\mathrm{EtOH}$ & 80 & $70-90$ & {$[19]$} \\
$\mathrm{CBSA}$ & Solvent-free & 100 & $85-93$ & {$[20]$} \\
$\mathrm{Fe}_{3} \mathrm{O}_{4} @ \mathrm{SiO}_{2} @ \mathrm{Ni}-\mathrm{Zn}-\mathrm{Fe} \mathrm{LDH}$ & Solvent-free & $70-80$ & $80-96$ & {$[21]$} \\
$\mathrm{MSNs}$ & Solvent-free & 80 & $82-95$ & {$[22]$} \\
$\mathrm{Fe}_{3} \mathrm{O}_{4} @ \mathrm{SiO}_{2}$ nanoparticles & Water & 100 & $82-95$ & {$[23]$} \\
$\mathrm{Fe}^{3+} / 4 \mathrm{~A}$ & EtOH & 80 & $70-99$ & This work \\
\hline
\end{tabular}

is clear from Table 4, our $\mathrm{Fe}^{3+} / 4 \mathrm{~A}$ catalyst is competitive with the published catalysts taking into account its efficacy and the simplicity of its preparation and the yield obtained. Further advantage of our catalyst, that it is reusable several times without any regeneration and without loss of activity.

\section{Conclusions}

In conclusion, iron on $4 \AA$ molecular sieves support proved to be efficient catalyst for the one-pot, four-component synthesis of 9-aryl-acridine-1,8-dione derivatives under mild, slightly basic conditions. The desired products were formed with good to excellent yields (50-99\%). The preparation of the catalyst is very simple and it can be reused several times without the significant loss of its activity.

Acknowledgments Open access funding provided by Budapest University of Technology and Economics (BME). Á. M. is grateful to the József Varga Foundation for the financial support.

\section{Compliance with Ethical Standards}

Conflict of interest The authors declare that they have no conflict of interest.

Open Access This article is distributed under the terms of the Creative Commons Attribution 4.0 International License (http://creativeco mmons.org/licenses/by/4.0/), which permits unrestricted use, distribution, and reproduction in any medium, provided you give appropriate credit to the original author(s) and the source, provide a link to the Creative Commons license, and indicate if changes were made.

\section{References}

1. Zhu J, Bienayme H (2005) Multicomponent reactions. Wiley, New York. ISBN: 3-527-30806-7.

2. Schramm M, Thomas G, Towart R, Franchowiak G (1983) Nature 303:535-537

3. Ramesh KB, Pasha MA (2014) Bioorg Med Chem Lett 24:3907-3913

4. Alvala M, Bhatnagar S, Ravi A, Jeankumar VU, Manjashetty TH, Yogeeswari P, Sriram D (2012) Bioorg Med Chem Lett 22:3256-3260

5. Patel MM, Mali MD, Patel SK (2010) Bioorg Med Chem Lett 20:6324-6326
6. Edraki N, Mehdipour AR, Khoshneviszadeh M, Miri R (2009) Drug Discov Today 14:1058-1066

7. Shanmugashundaran P, Prabahar KJ, Ramakrishnan VT (1993) J Heterocycl Chem 30:1003-1007

8. Srividya N, Ramamurthy P, Shanmugashundaran P, Ramakrishnan VT (1996) J Org Chem 61:5083-5089

9. Martín N, Quinteiro M, Seoane C, Soto JL, Mora A, Suárez M, Ochoa E, Morales A, del Bosque JR (1995) J Heterocycl Chem 32:235-238

10. Suárez M, Loupy A, Salfrán E, Morán L, Rolando E (1999) Heterocycles 51:21-27

11. Tu S-J, Lu Z, Shi D, Yao C, Gao Y, Guo C (2002) Synth Commun 32:2181-2185

12. Singh SK, Singh KN (2011) J Heterocycl Chem 48:69-73

13. Wang G-W, Xia J-J, Miao C-B, Wu X-L (2006) Bull Chem Soc Jpn 79:454-459

14. Li Y-L, Zhang M-M, Wang X-S, Shi D-Q, Tu S-J, Wei X-Y, Zong Z-M (2005) J Chem Res 2005:600-602

15. Shi D-Q, Ni S-N, Yang F, Shi J-W, Dou G-L, Li X-Y, Wang X-S (2008) J Heterocycl Chem 45:653-660

16. Fan X, Li Y, Zhang X, Qu G, Wang (2007) J Heteroatom Chem 18:786-790

17. Pasha MA, Khan R-ur-R, Ramesh KB (2016) Can Chem Trans 4:90-98

18. Kidwai M, Bhatnagar D (2010) Chem Pap 64:825-828

19. Nikpassand M, Mamaghani M, Tabatabaeian K (2009) Molecules 14:1468-1474

20. Davoodnia A, Khojastehnezhad A, Tavakoli-Hoseini N (2011) Bull Korean Chem Soc 32:2243-2248

21. Gilanizadeh M, Zeynizadeh B (2019) Polycycl Aromat Comp. https ://doi.org/10.1080/10406638.2019.1567560

22. Nasresfahani Z, Kassaee MZ (2015) Catal Commun 60:100-104

23. Dam B, Nandi S, Pal AK (2014) Tetrahedron Lett 55:5236-5240

24. Cwik A, Hell Z, Figueras F (2006) Adv Synth Catal 348:523-530

25. Cwik A, Hell Z, Figueras F (2006) Tetrahedron Lett 47:3023-3026

26. Cwik A, Hell Z, Figueras F (2005) Org Biomol Chem 3:4307-4309

27. Németh J, Hell Z (2013) React Kinet Mech Catal 111:115-121

28. Kiss A, Hell Z, Bálint M (2010) Org Biomol Chem 8:331-335

29. Fodor A, Kiss A, Debreczeni N, Hell Z, Gresits I (2010) Org Biomol Chem 8:4575-4581

30. Kiss A, Hell Z (2013) Synth Comm 43:1778-1786

31. Kiss A, Hell Z (2011) Tetrahedron Lett 52:6021-6023

32. Magyar Á, Hell Z (2016) Monatsh Chem 147:1583-1589

33. Magyar Á, Nagy B, Hell Z (2015) Catal Lett 145:1876-1879

34. Magyar Á, Hell Z (2019) Synlett 30:89-93

35. Magyar Á, Hell Z (2016) Catal Lett 146:1153-1162

36. Magyar Á, Hell Z (2017) Period Polytech Chem Eng 61:278-282

37. Magyar Á, Hell Z (2018) Green Proc Synth 7:316-322

Publisher's Note Springer Nature remains neutral with regard to jurisdictional claims in published maps and institutional affiliations. 